\title{
Optimization of bioscrubber systems to simultaneously remove methane and purify wastewater from intensive pig farms
}

\author{
Fang Liu ${ }^{a, b}$, Claudia Fiencke ${ }^{b}$, Jianbin Guo ${ }^{a^{*}}$, Tao Lyuc ${ }^{*}$, Renjie Dong ${ }^{a}$, Eva-Maria \\ Pfeiffer ${ }^{b}$ \\ ${ }^{a}$ College of Engineering, China Agricultural University, Qinghua East Road 17, 100083, Beijing, China \\ ${ }^{b}$ Center for Earth System Research and Sustainability, Institute of Soil Science, Universität Hamburg, \\ Allende-Platz 2, 20146, Hamburg, Germany \\ ' School of Animal Rural \& Environmental Sciences, Nottingham Trent University, Nottinghamshire \\ NG25 OQF, UK \\ *Corresponding authors: jianbinguo@cau.edu.cn (Jianbin Guo); tao.lyu@ntu.ac.uk (Tao Lyu).
}

\begin{abstract}
Use of bioscrubber is attracting increasing attention for exhaust gas treatment in intensive pig farm. However, the challenge is to improve the methane $\left(\mathrm{CH}_{4}\right)$ removal efficiency as well as the possibility of pig house wastewater treatment. Three laboratoryscale bioscrubbers, each equipped with different recirculation water types, livestock wastewater (10-times diluted pig house wastewater supernatant), a methanotroph growth medium (10-times diluted) and tap water, were established to evaluate the performance of $\mathrm{CH}_{4}$ removal and wastewater treatment. The results showed that high $\mathrm{CH}_{4}$ removal efficiency (25\%) can be rapidly achieved with improved methanotrophic activity due to extra nutrient support from the wastewater. The majority of the $\mathrm{CH}_{4}$ was removed in the middle to end part of the bioscrubbers, which indicated that $\mathrm{CH}_{4}$ removal could be potentially optimized by extending the length of the reactor. Moreover, $52 \%$ $86 \%$ of the ammonium $\left(\mathrm{NH}_{4}{ }^{+}-\mathrm{N}\right)$, total organic carbon (TOC) and phosphate $\left(\mathrm{PO}_{4}{ }^{3-} \mathrm{P}\right)$ removal were simultaneously achieved with $\mathrm{CH}_{4}$ removal in the present study. Based on these results, this study introduces a low-cost and simple-to-operate method to improve $\mathrm{CH}_{4}$ removal and simultaneously treat pig farm wastewater in bioscrubbers.
\end{abstract}

Keywords: Biofiltration; Climate change control; Greenhouse gas; Methanotroph activity; Pig farm wastewater

\section{Introduction}

The continued increase in greenhouse gas (GHG) concentrations due to anthropogenic activities has led to significant climatic changes (Cox et al., 2000), which have raised the global average temperature by approximately $0.6^{\circ} \mathrm{C}$ over the past century (Hansen et al., 2012). Carbon dioxide $\left(\mathrm{CO}_{2}\right)$ and methane $\left(\mathrm{CH}_{4}\right)$ are the two main GHGs in the Earth's atmosphere, but even though $\mathrm{CH}_{4}$ comprises a lower proportion 
(16\%) of the total anthropogenic GHG emission compared with $\mathrm{CO}_{2}(76 \%), \mathrm{CH}_{4}$ contributes 28 times the greenhouse effect of $\mathrm{CO}_{2}$ on a molar basis (IPCC, 2014). Thus, successfully mitigating $\mathrm{CH}_{4}$ emission could play an important role in global climate change control.

Of all $\mathrm{CH}_{4}$ emission sources, agriculture and its associated waste is a significant contributor, and the livestock industry is by far the largest emitter (57\%) in this category, which estimated at $195 \mathrm{Tg} \mathrm{CH}_{4} \mathrm{y}^{-1}$ (Saunois et al., 2016). Pork is the most widely consumed meat product in the world, and more than half of all pork production is now from intensive pig farms (Philippe \& Nicks, 2015), where $\mathrm{CH}_{4}$ is generated from the pig manure and flows out through the ventilation system (Haeussermann et al., 2006). Currently, pig farms are the second largest contributor (13\%) of GHG emissions in the livestock section (McLeod, 2011). Therefore, the treatment of $\mathrm{CH}_{4}$ from intensive pig farms represents a crucial issue to ensure sustainability in meat production and environmental protection.

Due to the low-cost and easy maintenance of packed-bed air scrubbers (also known as bioscrubbers or biotrickling filters), they have been widely applied as the endof-pipe technology to treat pig farm exhaust air in many European countries, including Germany, the Netherlands, and Denmark (Liu et al., 2014; Liu et al., 2017a; Melse \& Hol, 2017; Van der Heyden et al., 2015). In bioscrubbers, water is sprayed on the top of the packing materials and the exhaust gas enters from beneath the scrubber and flows upwards. These contrasting flow directions can provide intensive contact between the two, enabling the transfer of pollutants from the gas phase to the liquid phase. The packing materials act as the carrier to host methanotrophic bacteria (methanotrophs). As the mixture of exhaust gas and water passes through, $\mathrm{CH}_{4}$ can be adsorbed onto the surface of the packing material and/or into the attached biofilm and is oxidised by methanotrophs to achieve $\mathrm{CH}_{4}$ degradation (Aguilar et al., 2010; Liu et al., 2017b; Malhautier et al., 2005; Melse \& Timmerman, 2009; Melse \& van der Werf, 2005). However, compared to ammonia, the $\mathrm{CH}_{4}$ removal efficiencies are often relatively low, ranging from 0.9 - 6\% (Aguilar et al., 2010; Belzile et al., 2010). Thus, optimization of bioscrubbers to intensify $\mathrm{CH}_{4}$ removal is required, the relevant study is still lacking.

In field-scale bioscrubber systems, tap water is usually chosen as the spray water (recirculation water) for convenience. However, tap water contains low levels of nutrients and may lead to a long methanotrophic bacteria growth period. It may then cause low $\mathrm{CH}_{4}$ removal in bioscrubbers, because the biodegradation of $\mathrm{CH}_{4}$ is heavily reliant on methanotrophic abundance and activity (Yargicoglu \& Reddy, 2017). In addition to generating GHGs, pig farms also produce a large amount of wastewater, which need to be treated before discharge (Molina-Moreno et al., 2017). The sustainable concept allows us to consider reusing the high level of nutrients, e.g. nitrogen and 
phosphors, in the pig farm wastewater (Luo et al., 2017) to fed the methanotrophs. By doing so, it is hypothesised that the $\mathrm{CH}_{4}$ removal rate could be improved and the pig farm wastewater could simultaneously be purified in bioscrubbers after using this wastewater as the recirculation water. Moreover, using isolated methanotrophs as the biological additives has been demonstrated to significantly improve $\mathrm{CH}_{4}$ removal in bioscrubbers (Liu et al., 2017b). Whether the combination of pig farm wastewater and methanotroph addition could further improve bioscrubber performance requires investigation.

In this study, three laboratory-scale bioscrubbers equipped with different recirculation water types (pig farm wastewater (10-times diluted pig farm wastewater supernatant), methanotroph growth medium (10-times diluted) and tap water) were established to evaluate the $\mathrm{CH}_{4}$ treatment performance. The performance of the bioscrubbers by a stepwise change of the recirculation water to pig farm wastewater were also tested. Then, the methanotrophic activity and spatial variability of $\mathrm{CH}_{4}$ removal in bioscrubbers were studied to understand the underpinning mechanism. Furthermore, the pollutant (organic matter, nitrogen and phosphorous) removal efficiencies of the pig farm wastewater were investigated. With these results, this study aims to optimise bioscrubber systems to a low-cost and easy-to-operate technology to improve the $\mathrm{CH}_{4}$ removal and simultaneously treat pig farm wastewater.

\section{Materials and Methods}

\subsection{Experimental setup}

The three lab-scale bioscrubbers used in this study were made of identical polyvinyl chloride (PVC) columns with dimensions of $125 \times 30 \times 30 \mathrm{~cm}$ in height, length and width, respectively (Fig. 1). Each column was filled with stacks of coarse plastic square plate from 10 to $120 \mathrm{~cm}$ height with a final effective volume of $99 \mathrm{~L}$. This packing material was collected from the field-scale bioscrubbers with an operation time of around 7 years, which were employed at an intensive pig farm in Niedersachsen (Cloppenburg area), northern Germany. The packing material was made of polyethylene with $0.3 \mathrm{~m}$ in both length and width and $1.0 \mathrm{~cm}$ in thickness. The distance between each plate in the bioscrubbers was around $1 \mathrm{~cm}$. The stack was vertically packed with a $45^{\circ}$ tilt to the airflow direction in the columns. In the bottom of the column, $10 \mathrm{~cm}$ of recirculation water collection area was connected to the exterior $20 \mathrm{~L}$ water tank for water recirculation in the bioscrubber (Figure 1a). The total volume of the recirculation water for each bioscrubber was around $20 \mathrm{~L}$, comprised of $9 \mathrm{~L}$ water in the bottom of the bioscrubber and $11 \mathrm{~L}$ water in the recirculation tank. To sample from different heights of the bioscrubber, four tubes were placed at 35, 65, 95 and $125 \mathrm{~cm}$ height in the column and reached the centre of the column to exclude edge effects. All tubes were equipped with valves for gas sampling. The gas mixer device (HTK Hamburg GmbH, Hamburg, Germany) was used to control the inflow gas composition and flow rate by mixing the 
methane and air (Fig. 1a). The mixed air flowed upwards through the packed bed while water was sprayed simultaneously from the top.

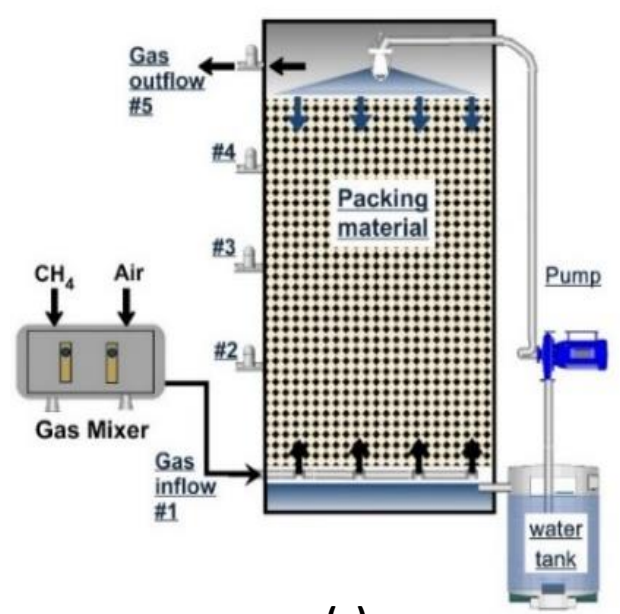

(a)

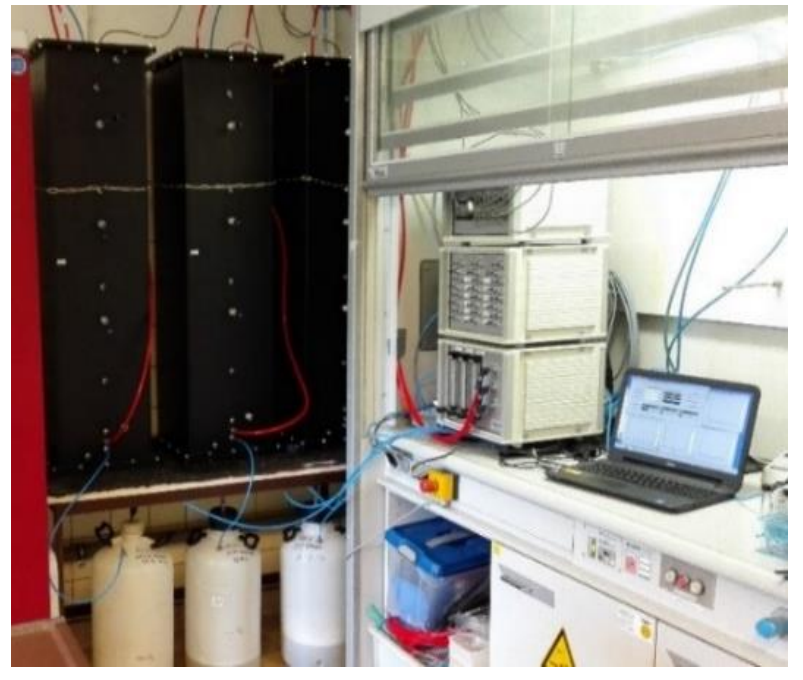

(b)

Fig.1 Schematic (a) and photo (b) of the lab-scale bioscrubber.

\subsection{Experimental conditions}

The experiment was conducted between May and December 2017, with a total duration of approximately 240 days. The experimental bioscrubbers were placed in the indoor laboratory at the Institute of Soil Science, Universität Hamburg, Germany (Fig. 1b). The indoor temperature ranged from 18 to $24^{\circ} \mathrm{C}$ during this period. Four continuous experimental phases (I, II, III and IV) were involved, based on varying recirculation water types and methanotroph addition (Table 1). To simulate the $\mathrm{CH}_{4}$ influent loading rate in the field-scale bioscrubber $\left(\sim 100 \mathrm{~g} / \mathrm{m}^{3} / \mathrm{h}\right)$, the $\mathrm{CH}_{4}$ inflow concentration, gas flow rate, empty bed retention time (EBRT), and recirculation water flow rate were kept at approximately $100 \mathrm{mg} / \mathrm{m}^{3}, 100 \mathrm{~m}^{3} / \mathrm{h}, 3.5 \mathrm{~s}$ and $0.15 \mathrm{~m}^{3} / \mathrm{h}$, respectively, throughout the experimental phases.

To investigate the effect of recirculation water types on the bioscrubbers' performance, tap water-diluted pig farm wastewater supernatant (90:10 by volume), tap water-diluted methanotroph cultivation medium ( $90: 10$ by volume) and tap water (100\%) were selected as the recirculation waters for bioscrubber 1 (BS1), bioscrubber 2 (BS2) and bioscrubber 3 (BS3), respectively, in phase I (60 days). In phase II (60 days), 2 L (10\% of the recirculation water) of methanotrophic solution was added to the recirculation water tanks for all BS recirculation tanks. In phase III (60 days), half the volume (10 L) of the recirculation water in BS2 and BS3 was changed to pig farm wastewater (same preparation as BS1 in phase I). For comparison, $10 \mathrm{~L}$ of fresh pig farm wastewater was also used to substitute the recirculation water in BS1. Finally, to confirm the effect of pig farm wastewater, the recirculation water in all the bioscrubbers was changed to fresh pig farm wastewater in phase IV (60 days). 
Table 1

Operating conditions of the three bioscrubbers across the experimental phases.

\begin{tabular}{|c|c|c|c|c|c|c|c|c|c|c|}
\hline \multirow[b]{2}{*}{ BS } & \multicolumn{4}{|c|}{ Recirculation water of each experimental phase in $3 \mathrm{BSs}$} & \multicolumn{6}{|c|}{ Operating conditions of 3 BSs during the whole experiment } \\
\hline & Phase I & Phase II & Phase III & Phase IV & $\begin{array}{l}\text { Packing } \\
\text { Volume } \\
\left(\mathrm{m}^{3}\right)\end{array}$ & $\begin{array}{l}\mathrm{CH}_{4} \text { inflow } \\
\text { concentration } \\
\left(\mathrm{mg} / \mathrm{m}^{3}\right)\end{array}$ & $\begin{array}{c}\text { Air } \\
\text { flow } \\
\text { rate } \\
\left(\mathrm{m}^{3} / \mathrm{h}\right) \\
\end{array}$ & $\begin{array}{c}\text { EBRT } \\
\text { (s) }\end{array}$ & $\begin{array}{c}\mathrm{CH}_{4} \\
\text { loading } \\
\text { rate } \\
\left(\mathrm{g} / \mathrm{m}^{3} / \mathrm{h}\right) \\
\end{array}$ & $\begin{array}{l}\text { Recirculation } \\
\text { water flow } \\
\text { rate }\left(\mathrm{m}^{3} / \mathrm{h}\right)\end{array}$ \\
\hline BS1 & $\begin{array}{l}\text { Wastewater } \\
\text { (20L) }\end{array}$ & $\begin{array}{l}\text { Wastewater (18L) } \\
\text { +Methanotroph (2L) }\end{array}$ & no change & Wastewater (20L) & & & & & & \\
\hline BS2 & $\begin{array}{l}\text { NMS medium } \\
\text { (20L) }\end{array}$ & $\begin{array}{l}\text { NMS medium (18L) } \\
\text { +Methanotroph (2L) }\end{array}$ & $\begin{array}{l}10 \mathrm{~L} \text { was } \\
\text { replaced } \\
\text { with } \\
\text { wastewater }\end{array}$ & Wastewater (20L) & 0.099 & 100 & 100 & 3.5 & 101 & 0.15 \\
\hline BS3 & $\begin{array}{l}\text { Tap Water } \\
\text { (20L) }\end{array}$ & $\begin{array}{c}\text { Tap water (18L) } \\
+ \text { Methanotroph (2L) }\end{array}$ & $\begin{array}{l}10 \mathrm{~L} \text { was } \\
\text { replaced } \\
\text { with } \\
\text { wastewater }\end{array}$ & Wastewater (20L) & & & & & & \\
\hline
\end{tabular}

$\mathrm{BS}, \mathrm{EBRT}$, and NMS medium represent the bioscrubber, empty bed retention time and 10-time diluted methanotroph growth medium; The wastewater represents 10-times diluted pig farm wastewater supernatant. 
The fresh pig farm wastewater supernatant was collected from the intensive pig farm in Niedersachsen (Cloppenburg area), northern Germany. The wastewater was kept in the storage tank after a pre-treatment of solid-liquid separation. The methanotrophic growth medium was prepared in the laboratory, which was a slightly modified nitrate mineral salts (NMS) medium (Whittenbury et al., 1970) and contained a $\mathrm{CuSO}_{4}$ concentration of $1 \mathrm{mg} / \mathrm{L}$.

Methanotrophs were isolated from the biofilm on the packing materials that were obtained from the field scale bioscrubber employed at the intensive pig farm in Niedersachsen. Type I methanotrophs, one species of Gammaproteobacteria, was the main methanotrophic bacteria in the biofilm, based on previous detection by an electron microscope (Liu et al., 2017b). The aforementioned NMS medium was used for bacterial enrichment. Enrichment occurred at $28^{\circ} \mathrm{C}$ under orbital shaking in rubber-stoppered $120 \mathrm{~mL}$ bottles, containing $30 \mathrm{~mL}$ of NMS medium, $0.3 \mathrm{~mL}$ of phosphate buffer solution, and the rest in gas phase. The gas phase was $10 \%$ methane synthetic air $\left(80 \% N_{2}, 20 \%\right.$ $\mathrm{O}_{2}$, and $0.03 \% \mathrm{CO}_{2}, \mathrm{Fa}$. Messer Griesheim) and the gas in the bottle was replaced every week for 2 months. After enrichment, the methanotroph solution was transferred and stored in $1 \mathrm{~L}$ amber bottles with $10 \%$ methane synthetic air at $4{ }^{\circ} \mathrm{C}$ in the dark prior to use.

\subsection{Sampling and analysis}

\subsubsection{Gas sample}

In each experimental phase, the first 32 days were run to stabilise the system under the new operation conditions. Triplicated samples were taken every seven days in the last four weeks of each phase for analysis. The gas samples from the inflow, the sample heights of 35, 65 and $95 \mathrm{~cm}$ and the outflow $(125 \mathrm{~cm})$ of the columns were taken. During sampling, $12 \mathrm{~mL}$ of gas was first discarded by a three-way cock, then $10 \mathrm{~mL}$ sample volumes were taken by a vacuum glass tubes $(10 \mathrm{~mL})$ equipped with single polypropylene fittings for gas analysis. The $\mathrm{CH}_{4}$ concentration was determined by a gas chromatograph (7890A, Agilent Technologies, US). The injection volume for analysis was $250 \mu \mathrm{L}$. Gases were separated on a Porapak Q column (1.8 m length, $2 \mathrm{~mm}$ ID) and quantified with a flame ionization detector (FID). The inflow, oven, and detector temperatures were $75^{\circ} \mathrm{C}, 35^{\circ} \mathrm{C}, 280^{\circ} \mathrm{C}$ (FID), respectively. Helium served as the carrier gas (30 mL/min).

\subsubsection{Water sample}

Following the gas sampling frequency, the $\mathrm{pH}$ and electrical conductivity $(\mathrm{EC})$ of the recirculation water were measured in the recirculation tank, using a $\mathrm{pH}$ meter ( $\mathrm{pH} /$ Cond 340i, WTW, Germany) and a potentiometer (Multi 350i, WTW, Germany), respectively. In experimental phase IV, $50 \mathrm{~mL}$ water samples were collected from each recirculation tank for quality analysis every week after the stabilization period. The 
analysed parameters included ammonia $\left(\mathrm{NH}_{4}{ }^{+}-\mathrm{N}\right)$, nitrate $\left(\mathrm{NO}_{3}{ }^{-}-\mathrm{N}\right)$, nitrite $\left(\mathrm{NO}_{2}^{-}-\mathrm{N}\right)$, total organic carbon (TOC) and phosphate $\left(\mathrm{PO}_{4}{ }^{3-}-\mathrm{P}\right)$. $\mathrm{NH}_{4}{ }^{+}-\mathrm{N}$ concentration was determined by a photometer according to German standard methods (DIN 38406-E5-1). $\mathrm{NO}_{3}^{-}-\mathrm{N}$ and $\mathrm{NO}_{2}{ }^{-}-\mathrm{N}$ were measured using a High Performance Liquid Chromatograph (HPLC 1200 Series, Agilent Technologies, USA) equipped with a C-18 column (Hypersil ODS, $125 \times 4.0$ $\mathrm{mm}, 5 \mu \mathrm{m}$, Agilent Technologies, USA) with a UV-Detector (model 430), according to the description by (Sanders et al., 2010). The total nitrogen (TN) content was calculated by the sum concentration of $\mathrm{NH}_{4}{ }^{+}-\mathrm{N}, \mathrm{NO}_{3}{ }^{-} \mathrm{N}$ and $\mathrm{NO}_{2}{ }^{-}-\mathrm{N}$. The TOC content was measured by a $\mathrm{C} / \mathrm{N}$ analyser (Variomax elementar $\mathrm{CNMS}$ ). The $\mathrm{PO}_{4}{ }^{3-}-\mathrm{P}$ concentration was determined using the colorimetric molybdenum blue reaction (Beermann et al., 2015). All the measurements were conducted in triplicate.

\subsubsection{Methanotrophic activity}

The methanotrophic activities in all bioscrubbers were estimated by measuring the methane removal intensity. Briefly, $150 \mathrm{~mL}$ interstitial water samples were collected from the water outlet in each bioscrubber at the end of each experimental phase. The $150 \mathrm{~mL}$ samples were placed in $250 \mathrm{~mL}$ plasma flasks filled with $50 \mathrm{~mL} \mathrm{NMS}$ medium. The flasks were then sealed with a rubber-stopper and cultivated under room temperature $\left(\sim 25^{\circ} \mathrm{C}\right)$ conditions for 20 days. An initial concentration of about $100 \mathrm{ppm}$ of $\mathrm{CH}_{4}$ was placed as the overlying gas in the flask. Each treatment was conducted in triplicate. In each flask, $250 \mu \mathrm{L}$ of the gas sample was taken to analyse the $\mathrm{CH}_{4}$ concentration by the previously described gas chromatography method (7890A, Agilent Technologies, US) on days 2, 3, 13 and 20, respectively. Thus, the $\mathrm{CH}_{4}$ degradation rate was used to reflect the potential methanotrophic activity.

\subsection{Calculation}

Methanotrophic activities were analysed for all the different BSs in each experimental phase. The $\mathrm{CH}_{4}$ degradation in the flask test was simulated by the first order kinetics model (equation 1 ):

$$
\mathrm{C}_{\mathrm{t}}=\mathrm{C}_{0} * \mathrm{e}^{-\mathrm{kt}}
$$

Where $C_{t}$ is the $\mathrm{CH}_{4}$ concentration at time point $t$ in ppm; $C_{0}$ is the initial concentration in ppm; $k$ is the reaction rate $d^{-1}$; $t$ is the reaction time.

After the simulation, the reaction rate ( $k$ value) was used to represent the potential methanotrophic activity.

\subsection{Statistical analysis}

Statistical analyses were carried out using the XLStat Pro® statistical software (XLStat, Paris, France). A one-way ANOVA and post-hoc Tukey's HSD test were used to compare average $\mathrm{CH}_{4}$ removal efficiencies, the potential methanotrophic activity, and the pollutants' removal abilities in pig farm wastewater between the three bioscrubbers under different experimental phases. All comparisons were assessed at the $95 \%$ ( $p<$ 
$0.05)$ and $99 \%(p<0.01)$ confidence levels. A linear regression model was used to simulate the methanotrophic activities and $\mathrm{CH}_{4}$ removal efficiencies in all bioscrubbers.

\section{Results}

\section{1 $\mathrm{CH}_{4}$ removal}

The $\mathrm{CH}_{4}$ removal efficiencies in different bioscrubbers across the four experimental phases are shown in Fig. 2 . After 32 days stabilization, BS1, equipped with the pig farm wastewater, showed significantly higher $\mathrm{CH}_{4}$ removal (average of $11 \%$ ) than that of BS2 (average of 6\%) and BS3 (average of $5 \%$ ), which were equipped with the NMS medium and tap water, respectively. In phase $\mathrm{II}$, the $\mathrm{CH}_{4}$ removal performances in BS1 and BS2 showed significant improvement after adding methanotrophs and reached $23 \%$ and $9 \%$, respectively. However, BS3 showed a slight improvement and achieved $6 \% \mathrm{CH}_{4}$ removal. After changing half of the recirculation water to pig farm wastewater in phase III, the $\mathrm{CH}_{4}$ removal efficiencies in BS2 and BS3 improved significantly to $15 \%$ and $12 \%$, respectively. In phase IV, all bioscrubbers showed similar $\mathrm{CH}_{4}$ removal (25\%) after totally

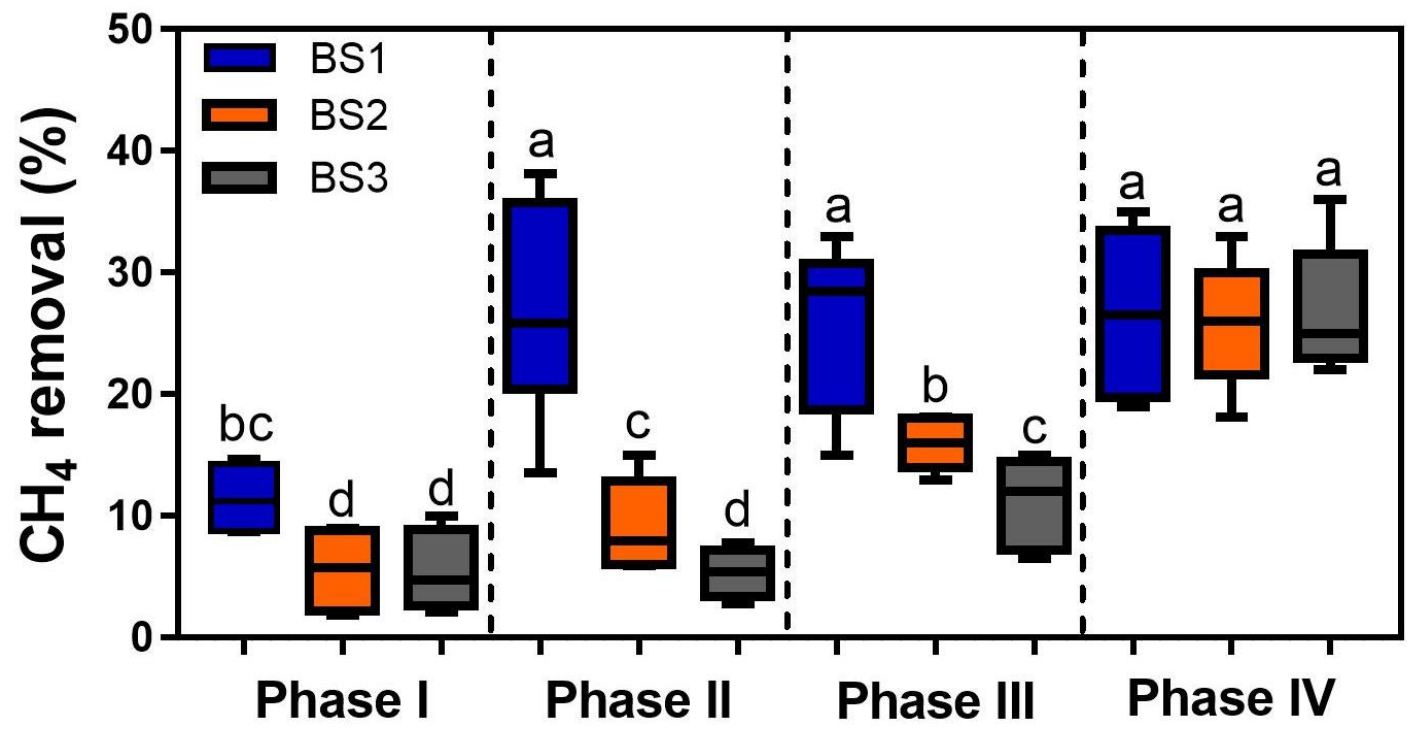

Fig. $2 \mathrm{CH}_{4}$ removal performance of the three bioscrubbers (BS) from Phase I to IV.

\section{2 $\mathrm{CH}_{4}$ removal profiles along the bioscrubbers}

$\mathrm{CH}_{4}$ concentrations gradually decreased from the inlet (bottom) to the outlet (top) along the gas flow pathway in all bioscrubbers (Fig. 3). Generally, the $\mathrm{CH}_{4}$ concentrations in three bioscrubbers did not show a clear difference at the sampling heights of $35 \mathrm{~cm}$ and $65 \mathrm{~cm}$ in any of the experiment phases. Significantly lower $\mathrm{CH}_{4}$ concentrations were observed at the sampling heights of $95 \mathrm{~cm}$ and $120 \mathrm{~cm}$ (out) in BS1 compared with those in BS2 and BS3 in phase I, II and III. When the operations were same in the three bioscrubbers in phase IV, the $\mathrm{CH}_{4}$ concentration profiles along the depth were similar between themselves (Fig. 3d). 


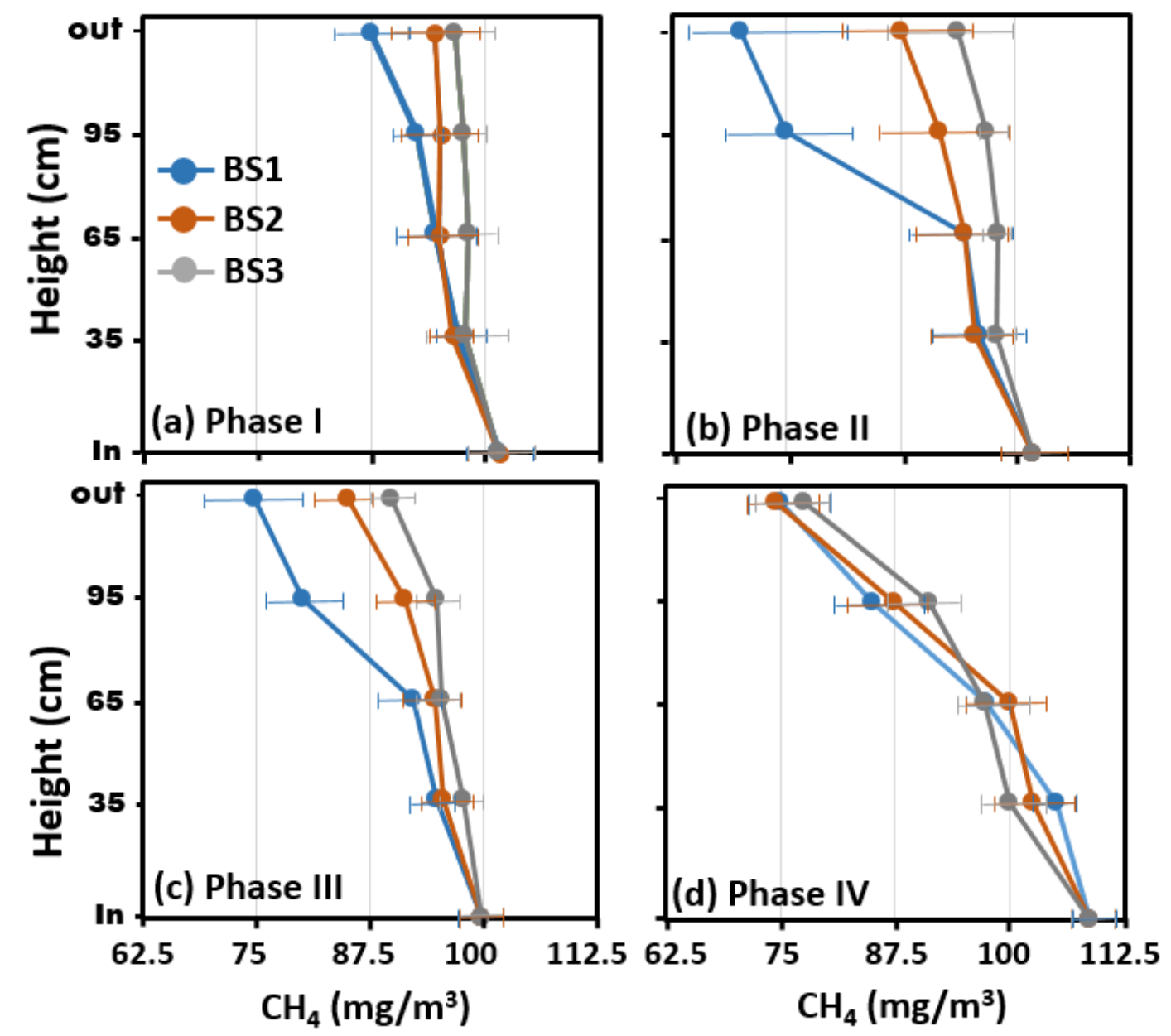

Fig. 3 Concentrations of $\mathrm{CH}_{4}$ at different depths in the three bioscrubbers (BS) from Phase I to phase IV.

\subsection{Methanotrophic activity}

In order to better understand the effect of pig farm wastewater and methanotroph addition on $\mathrm{CH}_{4}$ removal in bioscrubbers, the activities of methanotrophs were measured in the four experimental phases (Fig. 4). The experimental process was simulated using the first order kinetics model and the reaction rates ( $k$ values) were calculated to represent the methanotrophic activity. In phase I, the methanotrophic activity ( $k$ of $0.21 \mathrm{~d}^{-1}$ ) in BS1 was around 1 3 times higher than that of BS2 (k of $0.07 \mathrm{~d}^{-}$ $\left.{ }^{1}\right)$ and two orders of magnitude higher than that in BS3 ( $k$ of $\left.0.003 \mathrm{~d}^{-1}\right)$. After adding methanotrophs from Phase II, BS1 kept a relatively stable methanotrophic activity ( $\mathrm{k}$ of $0.34 \mathrm{~d}^{-1}$ ) until phase IV. Methanotrophic activity slightly increased in BS2 (k of $0.09 \mathrm{~d}^{-1}$ ) and BS3 ( $k$ of $0.05 \mathrm{~d}^{-1}$ ) in phase II. Nevertheless, after the replacement of the recirculation water in phase III and IV, methanotrophic activity in BS2 and BS3 continually improved and achieved a similar level $\left(k\right.$ of $\left.0.31 \mathrm{~d}^{-1}\right)$ to that of BS1. 

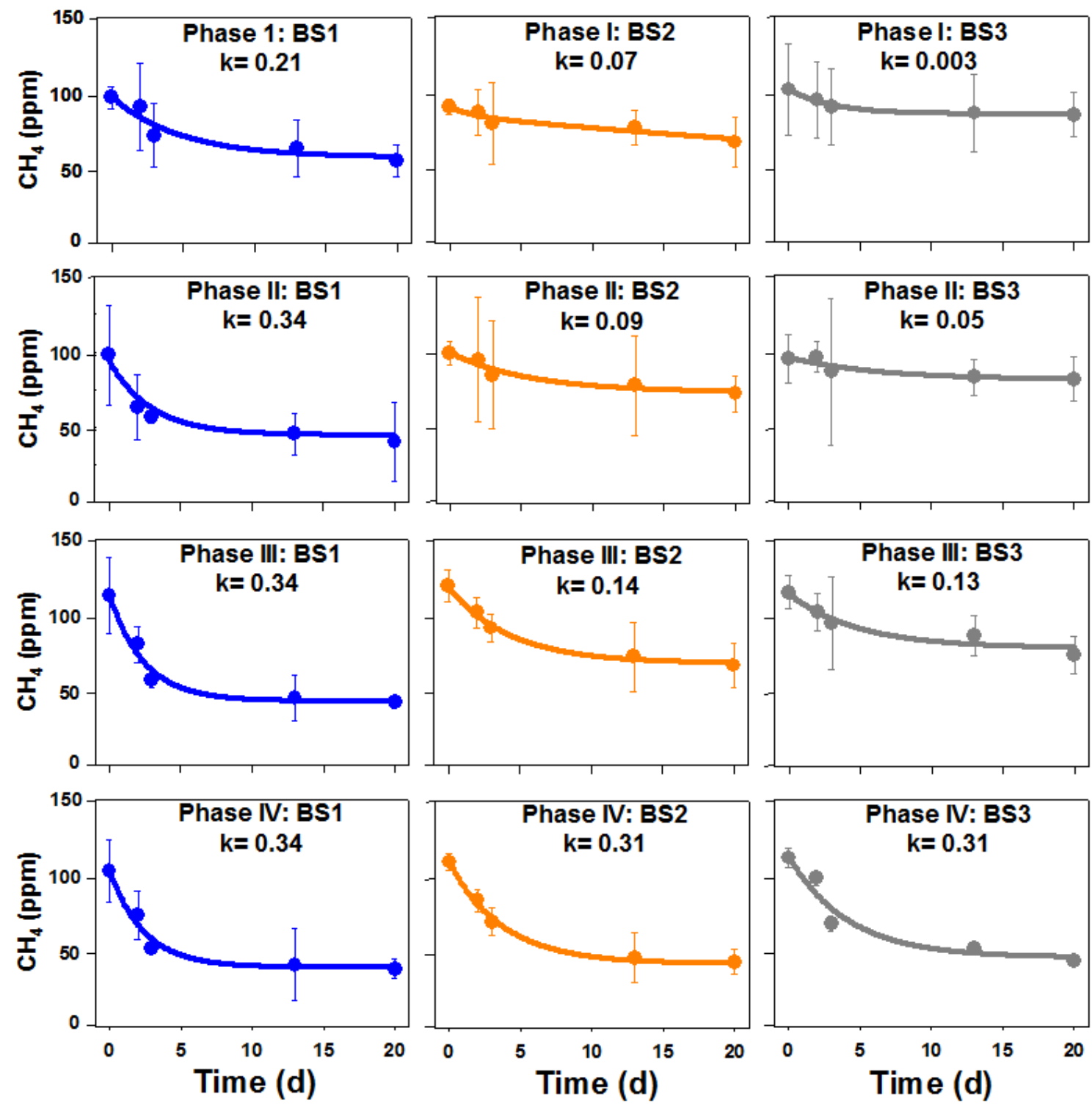

Fig. 4 Simulated methanotrophic activity in all bioscrubbers (BS) from Phase I to IV.

\subsection{Wastewater treatment performance}

To evaluate whether the pig farm wastewater can be purified during $\mathrm{CH}_{4}$ removal in bioscrubbers (BS), the water quality, $\mathrm{pH}$ and $\mathrm{EC}$, and concentrations of pollutants $\left(\mathrm{NH}_{4}{ }^{+}-\mathrm{N}, \mathrm{NO}_{3}^{-}-\mathrm{N}, \mathrm{NO}_{2}^{-}-\mathrm{N}, \mathrm{TOC}\right.$ and $\left.\mathrm{PO}_{4}{ }^{3-}-\mathrm{P}\right)$ were tested in phase IV (Table 2). The total nitrogen (TN) was calculated by the sum concentration of $\mathrm{NH}_{4}{ }^{+}-\mathrm{N}, \mathrm{NO}_{3}{ }^{-}-\mathrm{N}$ and $\mathrm{NO}_{2}{ }^{-}-\mathrm{N}$. At the beginning of phase IV, all bioscrubbers were equipped with fresh pig farm wastewater as their recirculation water. Generally, the bioscrubbers did not show significant differences for all the measured parameters. When compared with the initial 10 -time diluted pig farm wastewater, the EC values significantly increased from around $2.4 \mathrm{mS} / \mathrm{cm}$ to $5.2-5.9 \mathrm{mS} / \mathrm{cm}$ in the three bioscrubbers. The $\mathrm{pH}$ values did not show significant changes (6.2 - 7.3) compared with the initial wastewater (7.9). 
The initial pig farm wastewater contained high levels of $\mathrm{PO}_{4}{ }^{3-}-\mathrm{P}(11 \pm 3 \mathrm{mg} / \mathrm{L}), \mathrm{TOC}$ $(152 \pm 11 \mathrm{mg} / \mathrm{L}), \mathrm{TN}(39.4 \pm 5.3 \mathrm{mg} / \mathrm{L})$, and $\mathrm{NH}_{4}{ }^{+}-\mathrm{N}(36 \pm 5 \mathrm{mg} / \mathrm{L})$. The removal of $\mathrm{PO}_{4}{ }^{3-}-\mathrm{P}$ reached $73 \pm 3 \%, 64 \pm 3 \%$ and $64 \pm 4 \%$ in BS1, BS2 and BS3, respectively. The removal of TOC in the three bioscrubbers was found to be in the range of $74-86 \%$. The bioscrubbers provided removed $29 \pm 3 \%, 29 \pm 7 \%$, and $52 \pm 11 \%$ of the TN in BS1, BS2 and BS3, respectively. For different species comprising the $\mathrm{TN}, \mathrm{NH}_{4}{ }^{+}-\mathrm{N}$ removal was $64 \pm 4 \%, 52 \pm$ $8 \%$, and $73 \pm 15 \%$ in $\mathrm{BS} 1, \mathrm{BS} 2$ and $\mathrm{BS} 3$, respectively, while concentrations of $\mathrm{NO}_{3}{ }^{-} \mathrm{N}(2.3$ $\pm 0.2 \mathrm{mg} / \mathrm{L})$ and $\mathrm{NO}_{2}-\mathrm{N}(1.1 \pm 0.1 \mathrm{mg} / \mathrm{L})$ increased to $13 \pm 0.1$ and $3 \pm 0.2 \mathrm{mg} / \mathrm{L}$ in BS1, 9 \pm 1 and $2 \pm 0.2 \mathrm{mg} / \mathrm{L}$ in BS2, and $8 \pm 1$ and $1 \pm 0.1 \mathrm{mg} / \mathrm{L}$ in BS3, respectively.

\section{Table 2}

Pig farm wastewater treatment performance from the three bioscrubbers (BS) in phase IV.

\begin{tabular}{|c|c|c|c|c|c|c|c|}
\hline \multirow[t]{2}{*}{ Parameters } & \multirow{2}{*}{$\begin{array}{l}\text { Initial } \\
\text { Value }\end{array}$} & \multicolumn{2}{|l|}{ BS1 } & \multicolumn{2}{|l|}{ BS2 } & \multicolumn{2}{|l|}{ BS3 } \\
\hline & & Value & $\begin{array}{l}\text { Removal } \\
(\%)\end{array}$ & Value & $\begin{array}{l}\text { Removal } \\
(\%)\end{array}$ & Value & $\begin{array}{l}\text { Removal } \\
(\%)\end{array}$ \\
\hline $\mathrm{pH}$ & $7.9 \pm 0.1$ & $7.3 \pm 0.2$ & - & $6.2 \pm 0.4$ & - & $6.9 \pm 0.3$ & - \\
\hline $\mathrm{EC}(\mathrm{mS} / \mathrm{cm})$ & $2.4 \pm 0.5$ & $5.7 \pm 0.9 *$ & - & $5.2 \pm 1.2 *$ & - & $5.9 \pm 0.8 *$ & - \\
\hline $\mathrm{PO}_{4}{ }^{3-}-\mathrm{P}(\mathrm{mg} / \mathrm{L})$ & $11 \pm 3$ & $3 \pm 1 *$ & $73 \pm 3$ & $4 \pm 2 *$ & $64 \pm 3$ & $4 \pm 3 *$ & $64 \pm 4$ \\
\hline TOC (mg/L) & $152 \pm 11$ & $21 \pm 4 *$ & $86 \pm 5$ & $32 \pm 2 *$ & $79 \pm 6$ & $39 \pm 6 *$ & $74 \pm 7$ \\
\hline $\mathrm{TN}(\mathrm{mg} / \mathrm{L})$ & $39.4 \pm 5.3$ & $28 \pm 0.8^{*}$ & $29 \pm 3$ & $28 \pm 4.2^{*}$ & $29 \pm 7$ & $19 \pm 7.1^{*}$ & $52 \pm 11$ \\
\hline $\mathrm{NH}_{4}{ }^{+}-\mathrm{N}(\mathrm{mg} / \mathrm{L})$ & $36 \pm 5$ & $12 \pm 0.5^{*}$ & $66 \pm 4$ & $17 \pm 3^{*}$ & $52 \pm 8$ & $10 \pm 6^{*}$ & $73 \pm 15$ \\
\hline $\mathrm{NO}_{3}{ }^{-}-\mathrm{N}(\mathrm{mg} / \mathrm{L})$ & $2.3 \pm 0.2$ & $13 \pm 0.1^{*}$ & - & $9 \pm 1 *$ & - & $8 \pm 1 *$ & - \\
\hline $\mathrm{NO}_{2}{ }^{-}-\mathrm{N}(\mathrm{mg} / \mathrm{L})$ & $1.1 \pm 0.1$ & $3 \pm 0.2 *$ & - & $2 \pm 0.2 *$ & - & $1 \pm 0.1^{*}$ & - \\
\hline
\end{tabular}

* these values represent significant differences compared with the original 10-times diluted pig farm wastewater supernatant.

\section{Discussion}

According to the 2018 Global Report on Food Crises from the WFP (World Food Programme) (WFP, 2018), an estimated 124 million people in 51 countries are currently facing food insecurity and shortages. In order to produce more meat to fulfil the world consumption, livestock production has shifted from traditional, extensive, decentralized family farms to intensive livestock farms (Ilea, 2009). As a result, the livestock sector is now becoming one of the most significant contributors to environmental problems, including greenhouse gases emissions (Dennehy et al., 2017; Melse \& Mosquera, 2014), and water pollution (Mallin et al., 2015).

Traditionally, exhaust gases and wastewater from the intensive pig farms are treated separately by different technologies. Ecologically friendly biodegradation technologies, e.g. bioscrubbers and biofilters, are mainly equipped to purify the exhaust gases (Melse \& Timmerman, 2009). Pig farm wastewater, characterized by high concentrations of nutrients, e.g. organic matter and nitrogen, are usually treated by anaerobic digestion ( $\mathrm{Ni}$ et al., 2017) which is followed by post-treatment for nitrogen removal, such as ammonia stripping (Wu et al., 2018). However, a previous study has 
demonstrated the simultaneous removal of nitrogen from the swine wastewater and $\mathrm{H}_{2} \mathrm{~S}$ from the exhaust gas using a bubble column reactor (Deng et al., 2009). The present study uses an integrated approach to achieve simultaneous $\mathrm{CH}_{4}$ mitigation and wastewater treatment, which could provide a new insight for the future application of this technology.

The biodegradation of the pollutants from either the gas or water phase is heavily dependent on the bacterial growth in bioreactors, such as membrane bioreactors (Lebrero et al., 2014), anaerobic digesters (Zhang et al., 2012), constructed wetlands (Kizito et al., 2017), and bioscrubbers (Melse \& Hol, 2017). Thus, substances, such as activated sludge and livestock manure, with relative high concentrations of nutrients, are commonly used to prime the systems for bacteria growth. Based on the same concept, significantly higher $\mathrm{CH}_{4}$ removal in BS1 (11\%), compared with BS2 (6\%) and BS3 $(5 \%)$ in phase I (Fig. 2), could be due to the extra nutrients from pig farm wastewater for methanotroph growth. The $\mathrm{CH}_{4}$ removal in BS2 is higher than that in BS3 but lower than BS1, which may be because the 10-times diluted NMS medium contained less available nutrients for methanotroph growth compared with pig farm wastewater. Increasing the concentration of the NMS medium may improve the $\mathrm{CH}_{4}$ removal ability, however, the cost will also dramatically rise to affect the scalability.

Coupled with recirculating pig farm wastewater in the bioscrubber, extra methanotroph addition could further improve the $\mathrm{CH}_{4}$ removal from an average of $11 \%$ to $25 \%$ (Fig. 2). BS1 presented significantly higher $\mathrm{CH}_{4}$ removal percentages than BS2 and BS3 after the addition of methanotrophs, which may due to the nutrients from wastewater that can be utilized by the added bacteria to form a biofilm on the packing materials. This hypothesis was supported by the results of the potential methanotrophic activity, which had its highest value in BS1 after methanotroph addition (Fig. 4). The methanotroph activity was significantly positively correlated with the amount of $\mathrm{CH}_{4}$ removed (Fig. 5), which indicated that the methanotrophic activity in the recirculation water could be used to diagnose the $\mathrm{CH}_{4}$ removal ability of a bioscrubber.

To understand the $\mathrm{CH}_{4}$ removal processes inside bioscrubbers, the dynamics of the $\mathrm{CH}_{4}$ concentrations profile along the depth of the bioscrubbers though the four experimental phases were investigated (Fig. 3). The $\mathrm{CH}_{4}$ concentration changed the least at the bottom of the columns, however, the amount of $\mathrm{CH}_{4}$ heavily decreased (increased $\mathrm{CH}_{4}$ removal) from the middle to the outlet of the bioscrubbers. This increase in $\mathrm{CH}_{4}$ removal may be caused by an increased methanotrophic presence and activity at the middle to end part of the system. Recirculation water flows from the top to the bottom in bioscrubbers, thus, the nutrients may accumulate at the top first and to be easily and quickly utilized by methanotrophs. Previous studies have also demonstrated that the middle and top part of the biofilter system contained 1.1-2.5 fold methanotrophic 
activity compared with the bottom part when treating $\mathrm{CH}_{4}$ emissions from landfill (Pawłowska \& Stępniewski, 2006). The higher contact time between $\mathrm{CH}_{4}$ and the microbial community could also be contributing to the significant increase in $\mathrm{CH}_{4}$ removal along the length of the column (Gómez-Cuervo et al., 2016). However, more research is required to quantify the proportion and activity of the methanotrophs along the length of the bioscrubbers.

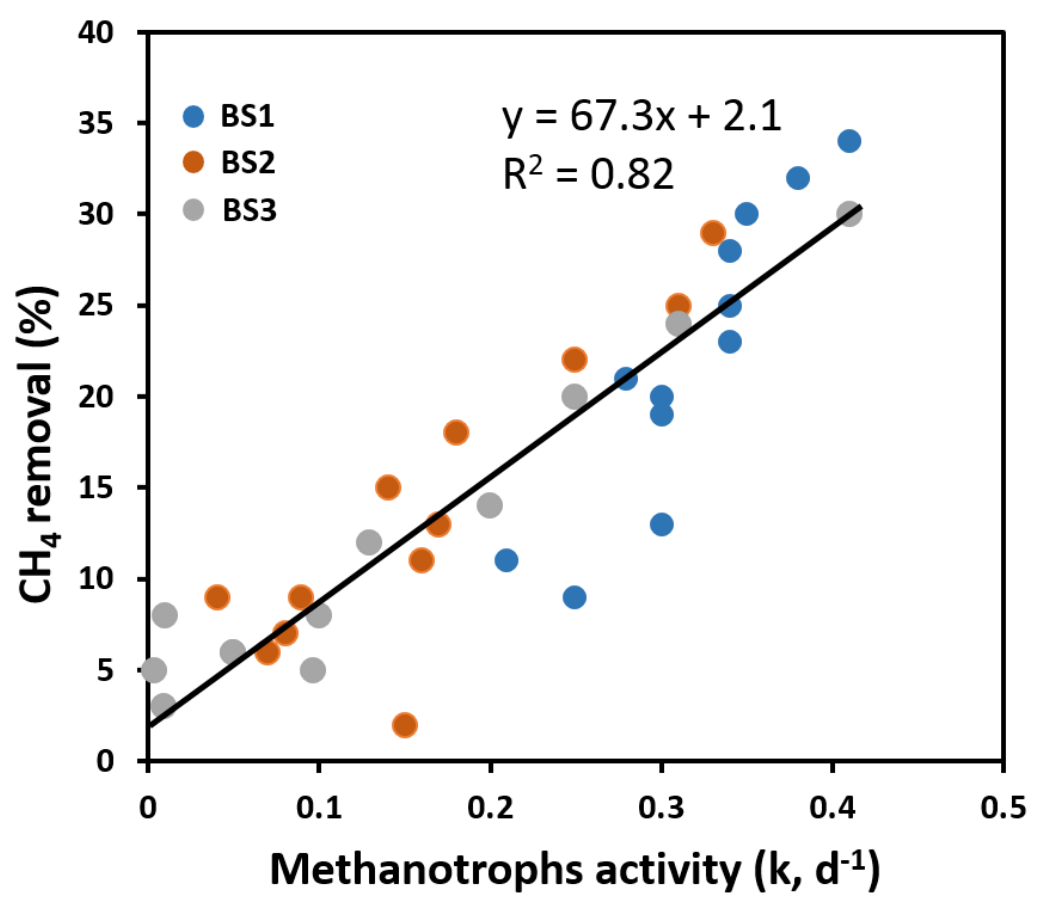

Fig. 5 The correlation between methanotrophic activity and $\mathrm{CH}_{4}$ removal efficiency

Under the present optimization methods, the bioscrubbers removed $52-86 \%$ of the $\mathrm{PO}_{4}{ }^{3-}-\mathrm{P}, \mathrm{TOC}$, and $\mathrm{NH}_{4}{ }^{+}-\mathrm{N}$ from the wastewater (Table 2), when associated with $\mathrm{CH}_{4}$ removal. $\mathrm{PO}_{4}{ }^{3-}-\mathrm{P}$, as an important nutrient, can be assimilated by numerous bacterial cells and supports their basic metabolisms (Liu et al., 2001; Smith \& Prairie, 2004). It can potentially support different bacteria, e.g. methanotrophs, organic degradation bacteria, nitrification/denitrification bacteria, which grow on the packing materials in bioscrubbers after introduced by wastewater. In addition to the oxidation of $\mathrm{CH}_{4}$, methanotrophic bacterial could also co-metabolise and degrade organic pollutants (Benner et al., 2015; Lyew \& Guiot, 2003), which may support TOC removal in bioscrubbers. The potential organic degradation bacteria may also contribute to the TOC removal (Li et al., 2018; Yamashita et al., 2015), however, the quantity and activity of this bacteria needs to be determined in future studies.

Methanotrophs has been demonstrated to be able to oxidize both $\mathrm{CH}_{4}$ and $\mathrm{NH}_{4}{ }^{+}-$ $\mathrm{N}$ (Bodelier \& Frenzel, 1999; Su et al., 2017), thus, the considerable $\mathrm{NH}_{4}{ }^{+}-\mathrm{N}$ removal in the bioscrubbers may be partly due to methanotrophic nitrification (Sutka et al., 2003). 
Moreover, the significantly increased concentrations of $\mathrm{NO}_{3}^{-}-\mathrm{N}$ and $\mathrm{NO}_{2}^{-}-\mathrm{N}$ (Table 2) supports the idea that the potential nitrification process (Kizito et al., 2017; Melse \& Hol, 2017), which was not measured in the present study, occurred in the bioscrubbers. Nevertheless, the TN removal was in the range of $29-52 \%$ in the three bioscrubbers (Table 2), which relatively low compared with other bioreactor systems for wastewater treatment (Yu et al., 2007). This may due to the preparation of artificial gas by mixing pure $\mathrm{CH}_{4}$ and air, which could aerate the bioscrubbers and result in aerobic conditions. The denitrification process, which could convert $\mathrm{NO}_{3}^{-}-\mathrm{N}$ and $\mathrm{NO}_{2}^{-}-\mathrm{N}$ to $\mathrm{N}_{2}$ for final nitrogen removal, would be heavily prohibited under these aerobic conditions. Real pig house exhaust gases could also contain other substances, such as $\mathrm{CO}_{2}, \mathrm{~N}_{2} \mathrm{O}, \mathrm{NH}_{3}$ (Melse \& Mol, 2004; Melse \& Mosquera, 2014), which could consume oxygen in the bioscrubber to reduce the aerobic condition. Thus, the TN removal may be improved when used in the real pig house exhaust gas treatment plant, however, this requires further study.

Theoretically, once the EC of the recirculation water exceeds $22 \mathrm{mS} / \mathrm{cm}$ in bioscrubber systems, the water needs to be refreshed to avoid the inhibition of the $\mathrm{CH}_{4}$ removal ability due to the high concentration of ions, e.g. $\mathrm{NH}_{3}{ }^{+}$, in the water. However, the EC in the present study, for all systems, only reached $5.9 \mathrm{mS} / \mathrm{cm}$ in phase IV when using 10-times diluted pig farm wastewater, making the implementation of this system feasible. However, it should be noted that the original pig farm wastewater may contain a high concentration solid particles and other pollutants, such as heavy metals (Shen et al., 2016), that may influence the bioscrubber efficiency. Thus, appropriate wastewater pre-treatments should be considered before applying these optimisations.

\section{Conclusions}

The proposed optimization methods for bioscrubbers, selecting pig farm wastewater as the recirculation water combined with isolated methanotroph addition, was demonstrated to be a promising strategy to simultaneously remove $\mathrm{CH}_{4}$ and purify pig farm wastewater. High $\mathrm{CH}_{4}$ removal efficiency (25\%) can be rapidly achieved with improved methanotrophic activity due to the extra nutrient support from the wastewater. The majority of the $\mathrm{CH}_{4}$ was removed in the middle to end part of the bioscrubbers. For the wastewater, removal of $52-86 \%$ of the $\mathrm{NH}_{4}{ }^{+}-\mathrm{N}, \mathrm{TOC}$ and $\mathrm{PO}_{4}{ }^{3-}-\mathrm{P}$ can be achieved in the present study.

\section{Acknowledgements}

The authors express their sincere acknowledgements to Wilfried Gläseker for his technical assistance. This work was financially supported by the German Federal Ministry of Education and Research (BMBF, support code 033RD1102B), National key research and development plan (Grant No. 2018YFD0800102), the Beijing municipal education commission joint building project (35030004), and the China Scholarship Council. 


\section{References}

Aguilar, M., Abaigar, A., Merino, P., Estellés, F., Calvet, S. 2010. Effect of a bioscrubber on NH3, $\mathrm{N} 2 \mathrm{O}, \mathrm{CH} 4$ and $\mathrm{CO} 2$ emissions from a pig facility in Spain. International Conference on Agricultural Engineering-AgEng 2010: towards environmental technologies, ClermontFerrand, France, 6-8 September 2010. Cemagref.

Beermann, F., Teltewskoi, A., Fiencke, C., Pfeiffer, E.-M., Kutzbach, L. 2015. Stoichiometric analysis of nutrient availability (N, P, K) within soils of polygonal tundra. Biogeochemistry, 122(2-3), 211-227.

Belzile, M., Lemay, S.P., Zegan, D., Feddes, J.J., Godbout, S., Larouche, J.-P., Martel, M. 2010. Reduction of gas and odour emissions from a swine building using a biotrickling filter. XVIIth World Congress of the International Commission of Agricultural Engineering. pp. 13-17.

Benner, J., De Smet, D., Ho, A., Kerckhof, F.-M., Vanhaecke, L., Heylen, K., Boon, N. 2015. Exploring methane-oxidizing communities for the co-metabolic degradation of organic micropollutants. Applied microbiology and biotechnology, 99(8), 3609-3618.

Bodelier, P.L., Frenzel, P. 1999. Contribution of methanotrophic and nitrifying bacteria to $\mathrm{CH} 4$ and $\mathrm{NH} 4+$ oxidation in the rhizosphere of rice plants as determined by new methods of discrimination. Applied and Environmental Microbiology, 65(5), 1826-1833.

Cox, P.M., Betts, R.A., Jones, C.D., Spall, S.A., Totterdell, I.J. 2000. Acceleration of global warming due to carbon-cycle feedbacks in a coupled climate model. Nature, 408(6809), 184.

Deng, L., Chen, H., Chen, Z., Liu, Y., Pu, X., Song, L. 2009. Process of simultaneous hydrogen sulfide removal from biogas and nitrogen removal from swine wastewater. Bioresource Technology, 100(23), 5600-5608.

Dennehy, C., Lawlor, P.G., Jiang, Y., Gardiner, G.E., Xie, S., Nghiem, L.D., Zhan, X. 2017. Greenhouse gas emissions from different pig manure management techniques: a critical analysis. Frontiers of Environmental Science \& Engineering, 11(3), 11.

Gómez-Cuervo, S., Hernández, J., Omil, F. 2016. Identifying the limitations of conventional biofiltration of diffuse methane emissions at long-term operation. Environmental technology, 37(15), 1947-1958.

Haeussermann, A., Hartung, E., Gallmann, E., Jungbluth, T. 2006. Influence of season, ventilation strategy, and slurry removal on methane emissions from pig houses. Agriculture, ecosystems \& environment, 112(2-3), 115-121.

Hansen, J., Sato, M., Ruedy, R. 2012. Perception of climate change. Proceedings of the National Academy of Sciences, 109(37), E2415-E2423.

Ilea, R.C. 2009. Intensive livestock farming: Global trends, increased environmental concerns, and ethical solutions. Journal of agricultural and environmental ethics, 22(2), 153-167.

IPCC. 2014. Climate change 2014: synthesis report. Contribution of Working Groups I, II and III to the fifth assessment report of the Intergovernmental Panel on Climate Change. Core Writing Team, R.K. Pachauri and L.A. Meyer (eds.)]. IPCC, Geneva, Switzerland, 151 pp.

Kizito, S., Lv, T., Wu, S., Zeeshan, A., Luo, H., Dong, R. 2017. Treatment of anaerobic digested effluent in biochar-packed vertical flow constructed wetland columns: Role of media and tidal operation. Science of The Total Environment, 592, 197-205.

Lebrero, R., Gondim, A.C., Pérez, R., García-Encina, P.A., Muñoz, R. 2014. Comparative assessment of a biofilter, a biotrickling filter and a hollow fiber membrane bioreactor for odor treatment in wastewater treatment plants. Water research, 49, 339-350.

Li, X., Zhang, M., Liu, F., Chen, L., Li, Y., Li, Y., Xiao, R., Wu, J. 2018. Seasonality distribution of the abundance and activity of nitrification and denitrification microorganisms in sediments of surface flow constructed wetlands planted with Myriophyllum elatinoides during swine wastewater treatment. Bioresource technology, 248, 89-97. 
Liu, D., Løkke, M.M., Riis, A.L., Mortensen, K., Feilberg, A. 2014. Evaluation of clay aggregate biotrickling filters for treatment of gaseous emissions from intensive pig production. Journal of environmental management, 136, 1-8.

Liu, F., Fiencke, C., Guo, J., Rieth, R., Cuhls, C., Dong, R., Pfeiffer, E.M. 2017a. Bioscrubber treatment of exhaust air from intensive pig production: Case study in northern Germany at mild climate condition. Engineering in Life Sciences, 17(4), 458-466.

Liu, F., Fiencke, C., Guo, J., Rieth, R., Dong, R., Pfeiffer, E.-M. 2017b. Performance evaluation and optimization of field-scale bioscrubbers for intensive pig house exhaust air treatment in northern Germany. Science of The Total Environment, 579, 694-701.

Liu, W.T., Nielsen, A.T., Wu, J.H., Tsai, C.S., Matsuo, Y., Molin, S. 2001. In situ identification of polyphosphate - and polyhydroxyalkanoate - accumulating traits for microbial populations in a biological phosphorus removal process. Environmental Microbiology, 3(2), 110-122.

Luo, H., Lv, T., Shi, M., Wu, S., Carvalho, P.N., Dong, R. 2017. Stabilization of Preliminary Anaerobically Digested Slurry in Post-Storage: Dynamics of Chemical Characteristics and Hygienic Quality. Water, Air, \& Soil Pollution, 228(8), 306.

Lyew, D., Guiot, S. 2003. Effects of aeration and organic loading rates on degradation of trichloroethylene in a methanogenic-methanotrophic coupled reactor. Applied microbiology and biotechnology, 61(3), 206-213.

Malhautier, L., Khammar, N., Bayle, S., Fanlo, J.-L. 2005. Biofiltration of volatile organic compounds. Applied microbiology and biotechnology, 68(1), 16-22.

Mallin, M.A., Mclver, M.R., Robuck, A.R., Dickens, A.K. 2015. Industrial swine and poultry production causes chronic nutrient and fecal microbial stream pollution. Water, Air, \& Soil Pollution, 226(12), 407.

McLeod, A. 2011. World livestock 2011-livestock in food security. Food and Agriculture Organization of the United Nations (FAO).

Melse, R., Mol, G. 2004. Odour and ammonia removal from pig house exhaust air using a biotrickling filter. Water Science and Technology, 50(4), 275-282.

Melse, R.W., Hol, J.M. 2017. Biofiltration of exhaust air from animal houses: Evaluation of removal efficiencies and practical experiences with biobeds at three field sites. Biosystems Engineering, 159, 59-69.

Melse, R.W., Mosquera, J. 2014. Nitrous oxide (N2O) emissions from biotrickling filters used for ammonia removal at livestock facilities. Water Science and Technology, 69(5), 994-1003.

Melse, R.W., Timmerman, M. 2009. Sustainable intensive livestock production demands manure and exhaust air treatment technologies. Bioresource Technology, 100(22), 5506-5511.

Melse, R.W., van der Werf, A.W. 2005. Biofiltration for mitigation of methane emission from animal husbandry. Environmental science \& technology, 39(14), 5460-5468.

Molina-Moreno, V., Leyva-Díaz, J.C., Llorens-Montes, F.J., Cortés-García, F.J. 2017. Design of indicators of circular economy as instruments for the evaluation of sustainability and efficiency in wastewater from pig farming industry. Water, 9(9), 653.

$\mathrm{Ni}$, P., Lyu, T., Sun, H., Dong, R., Wu, S. 2017. Liquid digestate recycled utilization in anaerobic digestion of pig manure: Effect on methane production, system stability and heavy metal mobilization. Energy, 141, 1695-1704.

Pawłowska, M., Stępniewski, W. 2006. An influence of methane concentration on the methanotrophic activity of a model landfill cover. Ecological Engineering, 26(4), 392-395.

Philippe, F.-X., Nicks, B. 2015. Review on greenhouse gas emissions from pig houses: Production of carbon dioxide, methane and nitrous oxide by animals and manure. Agriculture, Ecosystems \& Environment, 199, 10-25. 
Sanders, T., Fiencke, C., Pfeiffer, E.-M. 2010. Small-scale variability of dissolved inorganic nitrogen (DIN), $\mathrm{C} / \mathrm{N}$ ratios and ammonia oxidizing capacities in various permafrost affected soils of Samoylov Island, Lena River Delta, Northeast Siberia. Polarforschung, 80(1), 23-35.

Saunois, M., Bousquet, P., Poulter, B., Peregon, A., Ciais, P., Canadell, J.G., Dlugokencky, E.J., Etiope, G., Bastviken, D., Houweling, S. 2016. The global methane budget 2000-2012. Earth System Science Data (Online), 8(2).

Shen, Y., Ye, Z.-L., Ye, X., Wu, J., Chen, S. 2016. Phosphorus recovery from swine wastewater by struvite precipitation: compositions and heavy metals in the precipitates. Desalination and Water Treatment, 57(22), 10361-10369.

Smith, E.M., Prairie, Y.T. 2004. Bacterial metabolism and growth efficiency in lakes: the importance of phosphorus availability. Limnology and Oceanography, 49(1), 137-147.

Su, Y., Lammers, M., Zhang, Y., van Bree, L., Liu, Z., Reichart, G.-J., Middelburg, J.J. 2017. Sources of organic matter for bacteria in sediments of Lake Rotsee, Switzerland. Journal of Paleolimnology, 58(3), 391-402.

Sutka, R., Ostrom, N., Ostrom, P., Gandhi, H., Breznak, J. 2003. Nitrogen isotopomer site preference of $\mathrm{N} 2 \mathrm{O}$ produced by Nitrosomonas europaea and Methylococcus capsulatus Bath. Rapid Communications in Mass Spectrometry, 17(7), 738-745.

Van der Heyden, C., Demeyer, P., Volcke, E.I. 2015. Mitigating emissions from pig and poultry housing facilities through air scrubbers and biofilters: State-of-the-art and perspectives. Biosystems Engineering, 134, 74-93.

WFP. 2018. 2018 Global Report on Food Crises. World Food Programme. https://www.wfp.org/content/global-report-food-crises-2018.

Whittenbury, R., Phillips, K., Wilkinson, J. 1970. Enrichment, isolation and some properties of methane-utilizing bacteria. Microbiology, 61(2), 205-218.

$\mathrm{Wu}, \mathrm{H}$. , Dong, R., Wu, S. 2018. Exploring low-cost practical antifoaming strategies in the ammonia stripping process of anaerobic digested slurry. Chemical Engineering Journal, 344, 228-235.

Yamashita, T., Yamamoto - Ikemoto, R., Yokoyama, H., Kawahara, H., Ogino, A., Osada, T. 2015. Mitigation of nitrous oxide (N2O) emission from swine wastewater treatment in an aerobic bioreactor packed with carbon fibers. Animal Science Journal, 86(3), 358-368.

Yargicoglu, E.N., Reddy, K.R. 2017. Microbial Abundance and Activity in Biochar-Amended Landfill Cover Soils: Evidence from Large-Scale Column and Field Experiments. Journal of Environmental Engineering, 143(9), 04017058.

Yu, X., Qi, Z., Zhang, X., Yu, P., Liu, B., Zhang, L., Fu, L. 2007. Nitrogen loss and oxygen paradox in full-scale biofiltration for drinking water treatment. Water research, 41(7), 1455-1464.

Zhang, W., Guo, J., Wu, S., Dong, R., Zhou, J., Lang, Q., Li, X., Lv, T., Pang, C., Chen, L. 2012. Effects of $\mathrm{Fe} 2+$ on the Anaerobic Digestion of Chicken Manure: A Batch Study. Digital manufacturing and automation (ICDMA), 2012 third international conference on. IEEE. pp. 364-368. 